DOI https://doi.org/10.30525/978-9934-588-47-1.12

\title{
ОЦНКА ЕФЕКТИВНОСТІ МОДЕЛІ ПАРАМЕТРИЧНОГО СИНТЕЗУ ДЛЯ ВИБОРУ ЕЛЕМЕНТНОЇ БАЗИ СИСТЕМ УПРАВЛІННЯ ТЕХНОЛОГІЧНИМИ ПРОЦЕСАМИ ВИРОБНИЦТВА РЕА
}

\author{
Мосьпан Д. В., Фомовська О. В.
}

\section{ВСТУП}

Бурхливий розвиток мікроелектроніки за останні 25 років зробив очевидним розуміння того, що необхідна радикальна зміна та вдосконалення методів складання виробів для всіх областей іiі застосування. Мініатюризація радіо- електронних апаратів (PЕА) призвела до повсюдного використання технології поверхневого монтажу (SMT - Surface Mount Technology) замість класичного вивідного монтажу (ТHT - Through Hole Technology), при виробничому складанні електронних модулів 0 i 1 структурних рівнів. Це дало не тільки зменшення масо-габаритних параметрів, а й значне підвищення якості та надійності виробів завдяки застосуванню більш сучасних матеріалів і компонентів. Важливим фактором є значне зменшення трудомісткості виробничих циклів із подальшим зниженням собівартості виробів і досягнення сучасного технічного рівня, що відповідає сучасним стандартам (ISO 9000).

Підвищення конкурентоспроможності продукції, що випускається, в першу чергу залежить від ефективності функціонування підприємства в цілому. При цьому максимум можливостей у даному напрямку може бути реалізованим тільки в тому випадку, якщо технологічні процеси $є$ оптимізованими за єдиним критерієм оптимізації. Наявність декількох варіантів вирішення такого завдання призводить до задачі вибору найкращого варіанту технологічного процесу (ТП), який має назву оптимального. За своєю суттю такі зміни технологічного процесу відповідають структурній оптимізації, хоча часто густо плутають це поняття з визначенням екстремального керування за якимось одним вхідним параметром. 
Розроблення єдиного критерію ефективності використання ресурсів $^{1}$ дала можливість запропонувати загальну первинну оцінку, проте технологія його практичного використання торкається низки моментів, які вимагають більш докладного розгляду. Це стосується визначення вартісних оцінок технологічних продуктів, особливо зношення робочого механізму, який реалізує базову функцію досліджуваної системи ${ }^{2}$. Таким чином, одною з задач даної роботи $є$ параметрична оптимізація, що базується на підставі дослідження сумарного впливу набору вхідних параметрів на режими проведення технологічних процесів зі зміною параметрів вихідних продуктів.

Одним із поширених технологічних процесів виробництва корпусів та кожухів РЕА $є$ холодне листове штампування (ХЛШ), яке дозволяє виготовляти вироби 3 підвищеною продуктивністю і коефіцієнтом використання металу, зниженими енерговитратами ${ }^{3}$. На поточний час межі промислового використання технології ХЛШ постійно розширюються в напрямку ускладнення геометричної форми виробів, скорочення кількості переходів штампування, зниження собівартості виробів, що збільшує конкурентоспроможність вказаної технології .

Оснащення технологічних процесів ХЛШ являє собою важливе завдання, особливо в сучасних умовах, коли для досягнення вищенаведених показників необхідна модернізація наявного обладнання та систем його управління ${ }^{5}$. Така модернізація пов'язана 3 упровадженням новітніх систем автоматичного управління, які побудовані на сучасному елементному базисі, та оцінки їх ефективності.

${ }^{1}$ Lutsenko I. Deployed model of extremal system operation for solving optimal management problems. Eastern-European Journal of Enterprise Technologies. 2014. 5/2(71). P. 61-66. DOI: 10.15587/1729-4061.2014.28592.

${ }^{2}$ Lutsenko I. Optimal control of systems engineering. Development of a general structure of the technological conversion subsystem. Eastern-European Journal of Enterprise Technologies. 2015. Vol. 1, Issue 2 (73). P. 43-50. DOI: 10.15587/17294061.2015.36246.

3 Клещов Г.М. Інформаційні конструкторські масиви штампів холодної листової штамповки. Вісник Інженерної академії України. 2010. № 3. С. 74-77.

4 Калюжний В. Л. Холодне штампування виробу 3 двома фланцями із листової заготовки шляхом використання операцій витягування, роздачі i осаджування. Збірник наукових праць Полтавського національного технічного університету ім. Ю. Кондратюка. Сер.: Галузеве машинобудування, будівниитво. 2013. № 2. С. 105-110.

5 Шамарін Ю.С., Тітов В.А., Носар Є.А. Напрямки модернізації штамувального обладнання. Journal of Mechanical Engineering NTUU «Kyiv Polytechnic Institute». 2011. № 62. C. 92-94. 
Обладнання для ХЛШ в загальному випадку являє собою складні, багатокомпонентні ієрархічні структури зі складними взаємозв'язками складових елементів та має велике різноманіття конструкцій, що відрізняються за конфігурацією, виконуваними функціями, ступенем універсальності і типізації, що, у свою чергу, викликає необхідність аналізу безлічі елементів, виконання компонувальних робіт, здійснення інженерних розрахунків й ін.

Тому актуальними $є$ розроблення та створення технологій ${ }^{6}$, математичних моделей формоутворення виробів, проектування штампового оснащення та прогнозування його довговічності 3 метою забезпечення експлуатаційної надійності й довговічності машин, агрегатів і деталей ${ }^{7}$.

У даній роботі використані відомі наукові напрямки, пов'язані 3 розробленням моделей параметричного синтезу системи автоматичного управління 8 .

Ураховуючи вищезгадане, можемо визначити, що метою даної роботи є розроблення узагальненої моделі параметричного синтезу систем автоматизованого управління (САУ) та окремих моделей параметричного синтезу елементів САУ, які дозволять з єдиних критеріальних позицій комплексно вирішити задачу системного синтезу САУ за багатьма критеріями 3 наступною оцінкою ефективності обраних рішень.

\section{1. Метод оптимального управління в енергосмних технологічних процесах виробництва РЕА}

Підвищення конкурентоспроможності підприємства в першу чергу залежить від ефективності його поточного функціонування. При цьому максимум можливостей у цьому напрямку може бути реалізований тільки в тому випадку, якщо цілі функціонування всіх

6 Калюжний В.Л. Створення інформаційних технологій реалізації інтенсивного пластичного деформування матеріалів та поверхневого зміцнення при виготовленні деталей для забезпечення надійності та довговічності штампів: звіт про НДР (заключ.). НТУУ «КПІ». 2010.

7 Мосьпан Д.В., Наумова Е.А., Воронин А.В., Драгобецкий В.В. Корректировка режимов упрочнения пластическим деформированием. Вестник Нац. техн. ун-та «ХПИ»: сб. науч. тр. Темат. вып. : Инновационные технологии и оборудование обработки материалов в машиностроении $и$ металлургии. - Харьков : НТУ «ХПИ». 2014. № 43(1086). С. 117-122.

${ }^{8}$ Невлюдов І.Ш., Токарєва О.В. Автоматичне управління технологічними об'єктами: Підручник. Київ : НАУ, 2018. 200 с. 
систем підприємства $є$ узгодженими, а процеси цих систем $\epsilon$ оптимізованими за єдиним критерієм оптимізації.

Створення моделі цільової розгорнутої операції дозволило розробити єдиний критерій ефективності використання ресурсів. Однак технологія його практичного використання торкається низки моментів, що вимагають більш докладного роз'яснення.

Це стосується побудови архітектури керованої системи і визначення вартісних оцінок технологічних продуктів, особливо зношення робочого механізму, що реалізує базову функцію досліджуваної системи.

Загальною тенденцією системотехніки є сприйняття систем САУ як об'єктів, технологічні процеси яких підлягають оптимізації9 .

Практичному використанню принципів оптимального управління заважає невизначеність, пов'язана 3 підміною понять, коли пошук екстремуму визначають як пошук оптимуму.

При цьому можливі п’ять основних варіантів. Вибір управління грунтується:

- на пошуку екстремуму деякого технічного параметра;

- на економічному показнику (прибутку, витратах, рентабельності);

- на синтетичному показнику, що об'єднує економічні та технічні параметри багатокритеріальної оптимізації;

- на мінімізації часу;

- на максимізації продуктивності ${ }^{10}$.

При цьому загальновідомо, що із двох варіантів управління кращим вважається той, який $\epsilon$ більш ефективним. Тобто оптимальним, за визначенням, $\epsilon$ управління, яке забезпечує найвищу ефективність процесу в рамках накладених обмежень.

Також загальновідомо, що для реалізації технологічної операції потрібні продукти перетворення та енергетичні, а на виході, після завершенню технологічної операції, формується споживчий продукт. У процесі функціонування техніка зношується, що призводить до споживання технічного продукту у вигляді зношення.

${ }^{9}$ Lutsenko I., Fomovskaya E. Identification of target system operations. The practice of determining the optimal control / Eastern-European Journal of Enterprise Technologies 2014. №.6(2(78)). P. 30-36. DOI: 10.15587/1729-4061.2015.54432.

${ }^{10}$ Zhang, S., Zhang C., Han G., Wang Q. Optimal Control Strategy Design Based on Dynamic Programming for a Dual-Motor Coupling-Propulsion System / The Scientific World Journal. 2014. Vol. 2014. P. 1-9. DOI: 10.1155/2014/958239. 
Грунтуючись на сказаному, можемо стверджувати, що ефективність операції залежить від відомих економічних показників, таких як витрати (RE) ${ }^{11}$, прибуток або додана вартість (PE-RE) i рентабельність [(PE-RE)/RE]. Дуже часто неадекватно оцінюють ефективність досліджуваної операції в загальному випадку, оскільки ці вирази, як мінімум, не побудовані 3 використанням всіх базових показників цільової операції.

Те ж можна сказати i про спроби оцінювати ефективність, спираючись на показник «час» або продуктивність.

Не виправляють ситуацію і синтетичні показники, в яких, на додаток до економічних показників, штучно додані якісь технологічні параметри. Аналогічні аргументи можна привести i щодо багатокритеріального підходу.

У роботі $^{12}$ запропоновано показник ефективності використання ресурсів, який спирається на базові показники цільової операції. Також розглядається проблема практичного використання розробленого критерію для вирішення завдання пошуку оптимального управління, що забезпечує вихід на найбільш ефективну цільову операцію.

Суть полягає в тому, що для вирішення задач подібного типу неможливо використовувати класичні методи через особливості технологічних операцій, якість вихідного продукту яких залежить від часу.

Крім того, можливість повноцінної оптимізації може бути отримана тільки в тому разі, коли досліджуваний процес не поєднує в собі декілька технологічних операцій, а вибір адекватного критерію оптимізації не означає автоматичне отримання достовірного результату без повного врахування всіх значущих чинників.

Тому метою даної роботи є дослідження факторів, що впливають на процес оптимізації системи автоматичного управління технологічними процесами виробництва елементів РЕА.

Виходячи зі сказаного, завданнями, вирішити які необхідно для досягнення поставленої мети, були обрані такі:

\footnotetext{
${ }^{11}$ Lapygin Y., Prokhorov N. Cost Management in the enterprise. Eksmo, 2007. $102 \mathrm{p}$

${ }^{12}$ Lutsenko I. Identification of target system operations. Development of global efficiency criterion of target operations / Eastern-European Journal of Enterprise Technologies. 2015. Vol. 2, Issue 2 (74). P. 35-40. DOI: 10.15587/17294061.2015.38963.
} 
- визначення зношення виробничих механізмів у залежності від управління;

- визначення кількісних інтегральних параметрів вхідних i вихідних продуктів системи у вартісних величинах, які можуть бути порівняними;

- визначення ефективності цільової операції на основі сигнатури мети, в залежності від управління;

- оцінка реакції критерію на зміну величини вартісної оцінки вихідного продукту;

- інтерпретація результатів дослідження.

\section{2. Узагальнена модель параметричного синтезу елементів САУ}

Після вибору типу i виду штампувальних пресів (ШП) визначаються вимоги і обмеження на системи автоматичного управління (САУ) та іiі елементи. Окремі моделі оцінки та вибору САУ і їі елементів відносяться до завдань параметричного синтезу.

Завдання параметричного синтезу елементів САУ полягає в такому ${ }^{13,14,15}$.

Відомо: безліч елементів САУ $E S=\left\{E S^{m}\right\} \quad E S=\left\{E S^{m}\right\}$, $m=1, m^{\prime}$.

Введемо змінну, $X_{\text {mow }}=\{0 ; 1\}$, де $X_{\text {mov }}=1$, якщо $m$-й елемент САУ обраний $o$-го типу $w$-го виду, $X_{\text {mov }}=0$ в іншому випадку.

Кожна САУ, характеризується низкою показників:

\section{- функціональні:}

1) надійність елементів САУ - $N_{\text {mow }}$;

2) напрацювання на відмову елементів САУ - NOT

3 ) статична помилка елементів САУ - $C T E_{\text {mow }}$;

4) кінетична помилка елементів САУ - $K E_{\text {mow }}$;

$5)$ час регулювання елементів САУ - $T R_{\text {mow }}$;

6) перерегулювання елементів САУ - $P R_{\text {mow }}$;

13 Дорф Р., Бишоп Р. Современные системы управления / Пер. с англ. Б.И. Копылова. Москва : Лаборатория Базовых Знаний, 2002. 832 с.

14 Парк Д., Маккей С. Сбор данных в системах контроля и управления. Москва : Группа ИДТ, 2006. 504 с.

${ }^{15}$ Гульков Г.И., Петренко Ю.Н., Раткевич Е.П., Симоненков О.Л. Системы автоматизированного управления електро-приводами. Москва : Новое знание, 2007. $400 \mathrm{c}$. 
7) амплітуда флуктуації елементів САУ - $S F_{\text {mow }}$;

8) стійкість елементів САУ - $P U_{\text {mow }}$;

9) обсяг елементів САУ $-G_{\text {mow }}$;

10) вага елементів САУ $-P_{\text {mow }}$;

11) температурний діапазон експлуатації елементів САУ $T R E_{\text {mow }}$;

12) діапазон вологості експлуатації елементів САУ - $D V E_{\text {mov }}$;

\section{- витратні:}

1) вартість елементів САУ - $C_{\text {mow }}$;

2) час проектування елементів САУ - TPR

3) кількість споживаної енергії елементів САУ - $P E N_{\text {mow }}$.

Як приватні критерії для вибору САУ можуть бути:

- максимальна надійність елементів САУ:

$$
N^{C A Y}=\max \sum_{m=1}^{3} \sum_{o=1}^{o^{m}} \sum_{w=1}^{w^{o}} N_{m o w} X_{m o w}
$$

- максимальне напрацювання на відмову елементів САУ:

$$
N O T^{C A Y}=\max \sum_{m=1}^{3} \sum_{o=1}^{o^{m}} \sum_{w=1}^{w^{o}} N O T_{m o w} X_{m o w}
$$

- мінімальна статична помилка елементів САУ:

$$
C T E^{C A Y}=\min \sum_{m=1}^{3} \sum_{o=1}^{o^{m}} \sum_{w=1}^{w^{o}} C T E_{\text {mow }} X_{\text {mow }} ;
$$

- мінімальна кінетична помилка елементів САУ:

$$
K E^{C A Y}=\min \sum_{m=1}^{3} \sum_{0=1}^{o^{m}} \sum_{w=1}^{w^{0}} K E_{\text {mow }} X_{\text {mow }}
$$

- мінімальний час регулювання елементів САУ:

$$
T R^{C A Y}=\min \sum_{m=1}^{3} \sum_{o=1}^{o^{m}} \sum_{w=1}^{w^{0}} T R_{\text {mow }} X_{\text {mow }} ;
$$


- мінімальне перерегулювання елементів САУ:

$$
P R^{C A Y}=\min \sum_{m=1}^{3} \sum_{o=1}^{o^{m}} \sum_{w=1}^{w^{0}} P R_{\text {mow }} X_{\text {mow }} ;
$$

- мінімальна амплітуда флуктуації елементів САУ:

$$
S F^{C A Y}=\min \sum_{m=1}^{3} \sum_{o=1}^{o^{m}} \sum_{w=1}^{w^{0}} S F_{\text {mow }} X_{\text {mow }}
$$

- максимальна стійкість елементів САУ:

$$
P U^{C A Y}=\max \sum_{m=1}^{3} \sum_{o=1}^{o^{m}} \sum_{w=1}^{w^{0}} P U_{m o w} X_{m o w}
$$

- мінімальний обсяг елементів САУ:

$$
G^{C A Y}=\min \sum_{m=1}^{3} \sum_{o=1}^{o^{m}} \sum_{w=1}^{w^{0}} G_{m o w} X_{\text {mow }} ;
$$

- мінімальна вага елементів САУ:

$$
P^{C A Y}=\min \sum_{m=1}^{3} \sum_{o=1}^{o^{m}} \sum_{w=1}^{w^{0}} P_{\text {mow }} X_{\text {mow }} ;
$$

- мінімальна вартість елементів САУ:

$$
C^{C A Y}=\min \sum_{m=1}^{3} \sum_{o=1}^{o^{m}} \sum_{w=1}^{w^{0}} C_{m o w} X_{m o w}
$$

- мінімальний час проектування елементів САУ:

$$
T P R^{C A Y}=\min \sum_{m=1}^{3} \sum_{o=1}^{o^{m}} \sum_{w=1}^{w^{0}} T P R_{\text {mow }} X_{\text {mow }}
$$

- мінімальна кількість споживаної енергії елементів САУ: 


$$
P E N^{C A y}=\min \sum_{m=1}^{3} \sum_{o=1}^{o^{m}} \sum_{w=1}^{w^{0}} P E N_{m o w} X_{m o w} .
$$

Область допустимих рішень під час вибору елементів САУ визначається такими обмеженнями:

- надійність елементів САУ повинна бути більше заданої $N_{3}^{m}$ :

$$
\sum_{0=1}^{o^{3}} \sum_{w=1}^{w^{0}} N_{\text {mow }} X_{\text {mow }} \geq N_{3}^{m} ; m=1,3 ;
$$

- напрацювання на відмову елементів САУ повинна бути більше заданої $\mathrm{NOT}_{3}^{m}$ :

$$
\sum_{o=1}^{o^{3}} \sum_{w=1}^{w^{0}} N O T_{\text {mow }} X_{\text {mow }} \geq \operatorname{NOT}_{3}^{m} ; m=1,3
$$

- статична помилка елементів САУ повинна бути менше заданої $C T E_{3}^{m}$ :

$$
\sum_{o=1}^{o^{3}} \sum_{w=1}^{w^{0}} C T E_{\text {mow }} X_{\text {mow }} \leq C T E_{3}^{m} ; m=1,3 ;
$$

- кінетична помилка елементів САУ повинна бути менше заданої $K E_{3}^{m}:$

$$
\sum_{o=1}^{o^{3}} \sum_{w=1}^{w^{0}} K E_{\text {mow }} X_{\text {mow }} \leq K E_{3}^{m} ; m=1,3 ;
$$

- час регулювання елементів САУ має бути менше заданого $T R_{3}^{m}$ :

$$
\sum_{0=1}^{o^{3}} \sum_{w=1}^{w_{0}} T R_{\text {mow }} X_{\text {mow }} \leq T R_{3}^{m} ; m=1,3 ;
$$

- перерегулювання елементів САУ має бути менше заданого $P R_{3}^{m}$ :

$$
\sum_{o=1}^{o^{3}} \sum_{w=1}^{w^{0}} P R_{3}^{m} ; m=1,3 ;
$$


- амплітуда флуктуації елементів САУ повинна бути менше заданої $S F_{3}^{m}$ :

$$
\sum_{o=1}^{o^{3}} \sum_{w=1}^{w^{0}} S F_{\text {mow }} X_{\text {mow }} \leq S F_{3}^{C A Y} ; m=1,3
$$

- стійкість елементів САУ повинна бути більше заданої $P U_{3}^{m}$ :

$$
\sum_{o=1}^{o^{3}} \sum_{w=1}^{w^{0}} P U_{\text {mow }} X_{\text {mow }} \geq P U_{3}^{m} ; m=1,3 ;
$$

- параметри кожного елемента САУ ( $G X_{\text {mov }}$ - ширина, $G Y_{\text {mov }}-$ довжина, $G Z_{\text {mov }}$ - висота), повинні бути менше заданих $G X_{3}^{m}$, $G Y_{3}^{m}, G Z_{3}^{m}$ :

$$
\left\{\begin{array}{l}
\sum_{o=1}^{o^{3}} \sum_{w=1}^{w^{0}} G X_{\text {mow }} X_{\text {mow }} \leq G X_{3}^{m} \\
\sum_{o=1}^{o^{3}} \sum_{w=1}^{w^{0}} G Y_{\text {mow }} X_{\text {mow }} \leq G Y_{3}^{m} ; m=1,3 ; \\
\sum_{o=1}^{o^{3}} \sum_{w=1}^{w^{0}} G Z_{\text {mow }} X_{\text {mow }} \leq G Z_{3}^{m}
\end{array}\right.
$$

- вага елементів САУ повинна бути менше заданої $P_{3}^{m}$ :

$$
\sum_{o=1}^{o^{3}} \sum_{w=1}^{w_{0}} P_{m o v} X_{m o w} \leq P_{3}^{m} ; P=1,3
$$

- температурний діапазон експлуатації елементів САУ повинен бути більше нижньої межі $T R E_{3 H}^{m}$ і менше верхньої межі $T R E_{3 B}^{m}$ :

$$
T R E_{3 H}^{m} \leq \sum_{0=1}^{o^{3}} \sum_{w=1}^{w^{0}} T R E_{\text {mow }} X_{\text {mow }} \leq \operatorname{TRE}_{3 B}^{m} ; m=1,3
$$


- діапазон вологості експлуатації елементів САУ повинен бути більше нижньої межі $D V E_{3 H}^{m}$ і менше верхньої межі $D V E_{3 H}^{m}$ :

$$
D V E_{3 H}^{m} \leq \sum_{0=1}^{o^{3}} \sum_{w=1}^{w^{0}} D V E_{\text {mow }} X_{\text {mow }} \leq D V E_{3 B}^{m} ; m=1,3 ;
$$

- вартість елементів САУ повинна бути менше заданої $C_{3}^{m}$ :

$$
\sum_{0=1}^{o^{3}} \sum_{w=1}^{w_{0}} C_{\text {mow }} X_{\text {mow }} \leq C_{3}^{m} ; m=1,3 ;
$$

- час проектування елементів САУ має бути менше заданого $\operatorname{TPR}_{3}^{m}$ :

$$
\sum_{0=1}^{o^{3}} \sum_{w=1}^{w^{0}} T P R_{\text {mow }} X_{\text {mow }} \leq T P R_{3}^{m} ; m=1,3 ;
$$

- кількість споживаної енергії елементів САУ має бути менше заданої $P E N_{3}^{m}$ :

$$
\sum_{o=1}^{o^{3}} \sum_{w=1}^{w^{0}} P E N_{\text {mow }} X_{\text {mow }} \leq P E N_{3}^{m} ; m=1,3 ;
$$

- з безлічі елементів САУ може бути обраний тільки один:

$$
\sum_{o=1}^{o^{3}} \sum_{w=1}^{w^{0}} X_{\text {mow }}=1 ; m=1,3 .
$$

Математичні моделі (1) - (29) відноситься до завдань лінійного багатокритеріального дискретного програмування 3 булевими змінними. Їх рішення в загальному вигляді представляє значні труднощі, як через складність обчислень, так і 3-за можливості ідентифікації деяких характеристик тільки у процесі функціонування. Для іiі спрощення проводиться іiі декомпозиція на завдання оцінки i вибору елементів САУ - мікроконтролера (МК), частотного перетворювача (ЧП), вимірювального перетворювача (ВП). 


\section{3. Вибір типу і виду мікроконтролера}

Мікроконтролери можуть виконувати безліч типових функцій завдяки вбудованому обладнанню. Для виконання поставленої технічної задачі може знадобитися певний набір вбудованого обладнання, отже, не може оцінюватися ефективність МК, які не мають даного обладнання ${ }^{1617}$.

Відомо:

- безліч типів МК $C A Y^{1}=\left\{C A Y_{0}^{1}\right\}, o=1, o^{1}$;

- безліч видів в кожному типі МК $C A Y_{0}^{1}=\left\{C A Y_{0 w}^{1}\right\}, w=1, w^{o}$.

Отже, змінна $X_{1 o w}=1$, якщо МК обраний $o$-го типу $w$-го виду, $X_{\text {low }}=0$ в іншому випадку.

Необхідно визначити тип і вид МК, який характеризується низкою показників:

\section{- функціональні:}

1) надійність МК $O$-го типу $w$-го виду $-N_{\text {low }}$;

2 ) напрацювання на відмову МК $o$-го типу $w$-го виду $N O T_{1_{o w}}$;

3 ) тактова частота МК $o$-го типу $w$-го виду $-T F_{1 o w}$;

4) обсяг Flash МК $o$-го типу $w$-го виду $-V F_{1 o w}$;

$5)$ кількість портів у МК $o$-го типу $w$-го виду $-K V P_{\text {low }}$;

6) обсяг ЕЕРROM МК $o$-го типу $w$-го виду $-V E_{\text {low }}$;

7) обсяг RAM МК $o$-го типу $w$-го виду $-V R_{\text {low }}$;

$8)$ температурний діапазон роботи МК $O$-го типу $w$-го виду $T D_{\text {low }}$;

9) споживання енергії МК $o$-го типу $w$-го виду $-P E N_{1 o w}$;

\section{- витратні:}

1) вартість МК $o$-го типу $w$-го виду - $P E N_{1 o w}$;

Як приватні критерії для вибору МК можуть бути:

- максимальна надійність МК:

16 Парр Э. Программируемые контроллеры. Руководство для инженера. Programmable Controllers: An Engineer's Guide. Москва : Бином. Лаборатория знаний, 2007. 520 с.

17 Трамперт В. Измерение, управление и регулирование с помощью AVR микрокон-троллеров. Messen, Steuem und Regeln mit AVR-Mikrocontrollem. Москва : МК-Пресс, 2006. 208 с. 


$$
N^{M K}=\max \sum_{o=1}^{o^{1}} \sum_{w=1}^{w^{0}} N_{1_{o w}} X_{1 o w}
$$

- максимальне напрацювання на відмову МК:

$$
N O T^{M K}=\max \sum_{o=1}^{o^{1}} \sum_{w=1}^{w^{0}} N O T_{1 o w} X_{1 o w}
$$

- максимальна тактова частота МК:

$$
T F=\max \sum_{o=1}^{o^{1}} \sum_{w=1}^{w_{0}} T F_{1 o w} X_{1 o w}
$$

- максимальний обсяг Flash MК:

$$
V F^{M K}=\max \sum_{o=1}^{o^{1}} \sum_{w=1}^{w^{0}} V F_{1 o w} X_{1 o w}
$$

- максимальна кількість портів у МК:

$$
K V P^{M K}=\max \sum_{o=1}^{o^{1}} \sum_{w=1}^{w^{0}} K V P_{1 o w} X_{1 o w}
$$

- максимальний обсяг EЕРROM МК:

$$
V E^{M K}=\max \sum_{o=1}^{o^{1}} \sum_{w=1}^{w^{0}} V E_{10 w} X_{1 o w} ;
$$

- максимальний обсяг RAM МК:

$$
V R^{M K}=\max \sum_{o=1}^{o^{1}} \sum_{w=1}^{w_{0}} V R_{1 o w} X_{1 o w}
$$

- мінімальне споживання енергії МК: 


$$
P E N^{M K}=\min \sum_{o=1}^{o^{1}} \sum_{w=1}^{w^{0}} P E N_{1 o w} X_{1 o w} ;
$$

- мінімальна вартість МК:

$$
P E N^{M K}=\min \sum_{o=1}^{o^{1}} \sum_{w=1}^{w^{0}} P E N_{1 o w} X_{1 o w} .
$$

Область допустимих рішень під час вибору типу і виду МК визначається обмеженнями:

- надійність МК повинна бути більше заданої $N_{3}^{M K}$ :

$$
\sum_{o=1}^{o^{1}} \sum_{w=1}^{w^{0}} N_{1_{\text {ow }}} X_{1 o w} \geq N_{3}^{M K}
$$

- напрацювання на відмову МК повинне бути більше заданого $\mathrm{NOT}_{3}^{\mathrm{MK}}$ :

$$
\sum_{o=1}^{o^{1}} \sum_{w=1}^{w^{0}} N O T_{1 o w} X_{1 o w} \geq N O T_{3}^{M K}
$$

- тактова частота МК повинна бути більше заданої $T F_{3}^{M K}$ :

$$
\sum_{o=1}^{o^{1}} \sum_{w=1}^{w^{o}} T F_{1 o w} X_{1 o w} \geq T F_{3}^{M K}
$$

- обсяг Flash МК повинен бути більше заданого $V F_{3}^{M K}$ :

$$
\sum_{o=1}^{o^{1}} \sum_{w=1}^{w^{0}} C_{1 o w} X_{1 o w} \leq C_{3}^{M K}
$$

- кількість портів у МК має бути більше заданого $K V P_{3}{ }^{M K}$ : 


$$
\sum_{o=1}^{o^{1}} \sum_{w=1}^{w^{0}} K V P_{1 o w} X_{1 o w} \geq K V P_{3}^{M K} ;
$$

- обсяг EЕРROM MК повинен бути більше заданого $V E_{3}^{M K}$ :

$$
\sum_{o=1}^{o^{1}} \sum_{w=1}^{w^{0}} V E_{1 o w} X_{1 o w} \geq V E_{3}^{M K}
$$

- обсяг RAM MК повинен бути більше заданого $V R_{3}^{M K}$ :

$$
\sum_{o=1}^{o^{1}} \sum_{w=1}^{w^{0}} V R_{1 o w} X_{1 o w} \geq V R_{3}^{M K}
$$

- температурний діапазон роботи МК повинен бути більше нижньої межі $T D_{3 H}^{M K}$ і менше верхньої межі $T D_{3 в}^{M K}$ :

$$
T D_{3 H}^{M K} \leq \sum_{o=1}^{o^{1}} \sum_{w=1}^{w^{0}} T D_{1 o w} X_{1 o w} \leq T D_{3 B}^{M K}
$$

- споживання енергії МК має бути менше заданого $P E N_{3}^{M K}$ :

$$
\sum_{o=1}^{o^{1}} \sum_{w=1}^{w^{0}} P E N_{1 o w} X_{1 o w} \leq P E N_{3}^{M K}
$$

- вартість МК повинна бути менше заданої $C_{3}^{M K}$ :

$$
\sum_{o=1}^{o^{1}} \sum_{w=1}^{w^{0}} C_{1 o w} X_{1 o w} \leq C_{3}^{M K}
$$

- 3 безлічі типів і видів МК може бути обраний тільки один:

$$
\sum_{o=1}^{o^{1}} \sum_{w=1}^{w^{0}} X_{1 o w}=1
$$


Математична модель (30) - (49) відноситься до завдань лінійного багатокритеріального дискретного програмування 3 булевими змінними.

Відомо:

\section{4. Вибір типу і виду частотного перетворювача}

- безліч типів ЧП $C A Y^{2}=\left\{C A Y^{2}{ }_{o}\right\} ; o=1, o^{2}$;

- безліч видів у кожному типі ЧП $C A Y^{2}{ }_{o}=\left\{C A Y^{2}{ }_{o w}\right\} ; w=1, w^{o}$.

Отже, змінна $X_{2 o w}=1$, якщо, ЧП обраний $o$-го типу $w$-го виду, $X_{2 o w}=0$ в іншому випадку.

Необхідно визначити тип і вид ЧП, які характеризується низкою показників:

\section{- функціональні:}

1) надійність ЧП $o$-го типу $w$ - го виду $-N_{2 o w}$;

2 ) напрацювання на відмову ЧП $o$-го типу $w$-го виду $-N O T_{2 o w}$;

3 ) потужність ЧП $o$-го типу $w$ - го виду $-D W_{2 o w}$;

4 ) частота вихідної напруги ЧП $O$-го типу $w$-го виду - $F U_{2 o w}$;

$5)$ ступінь захисту ЧП $o$-го типу $w$-го виду $-S Z_{2 o w}$;

$6)$ температурний діапазон роботи ЧП $o$-го типу $w$-го виду $K U_{2 o w}$;

7) кількість вбудованих регуляторів в ЧП $o$-го типу $w$-го виду $K U_{2 o w}$;

$8)$ обсяг ЧП $o$-го типа $w$-го вида $-G_{2 o w}$;

9) вага ЧП $o$-го типа $w$-го вида $-P_{2 o w}$;

\section{- витратні:}

1) вартість ЧП $o$-го типу $w$-го виду $-C_{2 o w}$.

Як приватні критерії для вибору ПП можуть бути:

- максимальна надійність ЧП:

$$
N^{4 \Pi}=\max \sum_{o=1}^{o^{2}} \sum_{w=1}^{w^{0}} N_{2 o w} X_{2 o w} ;
$$

- максимальне напрацювання на відмову ЧП:

$$
N O T^{4 \Pi}=\max \sum_{o=1}^{o^{2}} \sum_{w=1}^{w^{0}} N O T_{2 o w} X_{2 o w} ;
$$


- максимальна потужність ЧП:

$$
D W^{4 \Pi}=\max \sum_{o=1}^{o^{2}} \sum_{w=1}^{w^{0}} D W_{2 o w} X_{2 o w} ;
$$

- максимальна частота вихідної напруги ЧП:

$$
F U^{4 \Pi}=\max \sum_{o=1}^{o^{2}} \sum_{w=1}^{w^{0}} F U_{2 o w} X_{2 o w} ;
$$

- максимальний ступінь захисту ЧП:

$$
S Z^{4 \Pi}=\max \sum_{o=1}^{o^{2}} \sum_{w=1}^{w^{0}} S Z_{2 o w} X_{2 o w} ;
$$

- максимальна кількість вбудованих регуляторів ЧП:

$$
K U^{4 \Pi}=\max \sum_{o=1}^{o^{2}} \sum_{w=1}^{w^{0}} K U_{2 o w} X_{2 o w} ;
$$

- мінімальний обсяг ЧП:

$$
G^{4 \Pi}=\min \sum_{o=1}^{o^{2}} \sum_{w=1}^{w^{0}} G_{2 o w} X_{2 o w} ;
$$

- мінімальна вага ЧП:

$$
P^{4 \Pi}=\min \sum_{o=1}^{o^{2}} \sum_{w=1}^{w^{0}} P_{2 o w} X_{2 o w} ;
$$

- мінімальна вартість ЧП:

$$
C^{4 \Pi}=\min \sum_{o=1}^{o^{2}} \sum_{w=1}^{w^{0}} C_{2 o w} X_{2 o w} .
$$


Область допустимих рішень при виборі типу i виду ЧП визначається обмеженнями:

- надійність ЧП повинна бути більше заданої $\forall U_{a l}=1$ :

$$
\sum_{o=1}^{o^{2}} \sum_{w=1}^{w^{0}} N_{2 o w} X_{2 o w} \geq N_{3}^{4 \Pi}
$$

- напрацювання на відмову ЧП повинна бути більше заданого $\mathrm{NOT}_{3}^{4 \Pi}$ :

$$
\sum_{o=1}^{o^{2}} \sum_{w=1}^{w^{0}} \mathrm{NOT}_{2 o w} X_{2 o w} \geq \mathrm{NOT}_{3}^{4 \Pi} ;
$$

- потужність ЧП повинна бути більше заданої $D W_{3}^{4 \Pi}$ :

$$
\sum_{o=1}^{o^{2}} \sum_{w=1}^{w^{0}} D W_{2 o w} X_{2 o w} \geq D W_{3}^{4 \Pi}
$$

- частота вихідної напруги ЧП повинна бути більше заданої $\mathrm{FU}_{3}^{\text {पा }:}$

$$
\sum_{o=1}^{o^{2}} \sum_{w=1}^{w^{0}} F U_{2 o w} X_{2 o w} \geq F U_{3}^{4 \Pi \Pi}
$$

- ступінь захисту ЧП повинна бути більше заданої $S Z_{3}^{4 \Pi}$ :

$$
\sum_{o=1}^{o^{2}} \sum_{w=1}^{w^{0}} S Z_{2 o w} X_{2 o w} \geq S Z_{3}^{4 \Pi}
$$

- температурний діапазон роботи ЧП повинен бути більше нижньої межі $T D_{3 H}^{4 \Pi}$ і менше верхньої межі $T D_{3 B}^{4 \Pi}$ :

$$
T D_{3 H}^{4 \Pi} \leq \sum_{o=1}^{o^{2}} \sum_{w=1}^{w^{0}} T D_{2 o w} X_{2 o w} \leq T D_{3 B}^{4 I \Pi} ;
$$


- кількість вбудованих регуляторів в ЧП повинно бути більше заданого $K U_{3}^{\text {чा }: ~}$

$$
\sum_{o=1}^{o^{2}} \sum_{w=1}^{w^{0}} K U_{2 o w} X_{2 o w} \geq K U_{3}^{4 \Pi} ;
$$

- параметри ЧП ( $G X_{2 o w}$ - ширина, $G Y_{2 o w}$ - довжина, $G Z_{2 o w}$ - висота), повинні бути менше заданих $G X_{3}^{4 \Pi}, G Y_{3}^{4 \Pi}, G Z_{3}^{4 \Pi}$ :

$$
\left\{\begin{array}{l}
\sum_{o=1}^{o^{2}} \sum_{w=1}^{w^{0}} G X_{2 o w} X_{2 o w} \leq G X_{3}^{4 \Pi} \\
\sum_{o=1}^{o^{2}} \sum_{w=1}^{w^{0}} G Y_{2 o w} X_{2 o w} \leq G Y_{3}^{4 \Pi} \\
\sum_{o=1}^{o^{2}} \sum_{w=1}^{w^{0}} G Z_{2 o w} X_{2 o w} \leq G Z_{3}^{4 \Pi}
\end{array}\right.
$$

- вага ЧП повинна бути менше заданої $P_{3}^{4 \Pi}$ :

$$
\sum_{o=1}^{o^{2}} \sum_{w=1}^{w^{0}} P_{2 o w} X_{2 o w} \leq P_{3}^{4 \Pi} ;
$$

- вартість ЧП повинна бути менше заданої $C_{3}^{4 \Pi}$ :

$$
\sum_{o=1}^{o^{2}} \sum_{w=1}^{w^{0}} C_{2 o w} X_{2 o w} \leq C_{3}^{4 \Pi}
$$

- 3 безлічі типів і видів ЧП може бути обраний тільки один:

$$
\sum_{o=1}^{o^{2}} \sum_{w=1}^{w^{0}} X_{2 o w}=1
$$

Математична модель (50) - (69) відноситься до завдань лінійного багатокритеріального дискретного програмування 3 булевими змінними. 


\section{5. Вибір типу і виду вимірювальних перетворювачів} Відомо:

- безліч типів ВП $C A Y^{3}=\left\{C A Y_{0}^{3}\right\} ; o=1, o^{3}$;

- безліч видів в кожному типі ВП $C A Y_{0}^{3}=\left\{C A Y^{3}{ }_{\text {ow }}\right\} ; w=1, w^{0}$.

Отже, змінна $X_{\text {зоw }}=1$, якщо ВП обраний $o$-го типу $w$-го виду, $X_{3 \text { ow }}=0$ в іншому випадку.

Необхідно визначити тип і вид ВП, які характеризується низкою показників:

\section{- функціональні:}

1) надійність ВП $O$-го типу $w$-го виду $-N_{3 o w}$;

2 ) напрацювання на відмову ВП $o$-го типу $w$-го виду $-N O T_{\text {зоw }}$;

3 ) діапазон виміру ВП $o$-го типу $w$-го виду $-D I_{3 о w}$;

4) динамічна точність ВП $O$-го типу $w$-го виду $-D Q_{3 o w}$;

$5)$ статична точність ВП $O$-го типу $w$-го виду $-S Q_{3 o w}$;

6) коефіцієнт перетворення ВП $O$-го типу $w$-го виду $-K P R_{3 о w}$;

7) потужність вихідного сигналу ВП $o$-го типу $w$-го виду $W S_{3 \text { зow }}$;

$8)$ стійкість ВП $O$-го типу $w$-го виду $-P U_{3 o w}$;

9) обсяг ВП $O$-го типу $w$-го виду $-G_{3 о w}$;

$10)$ вага ВП $O$-го типа $w$-го вида - $P_{3 o w}$;

\section{- витратні:}

1) вартість ВП $o$-го типа $w$-го вида $-C_{3 o w}$.

Як приватні критерії для вибору ВП можуть бути:

- максимальна надійність ВП:

$$
N^{B \Pi}=\max \sum_{o=1}^{o^{3}} \sum_{w=1}^{w^{0}} N_{3 o w} X_{3 o w} ;
$$

- максимальне напрацювання на відмову ВП:

$$
N O T^{B \Pi}=\max \sum_{o=1}^{o^{3}} \sum_{w=1}^{w^{0}} N O T_{30 w} X_{30 w} ;
$$

- максимальний діапазон виміру ВП: 


$$
D I^{B \Pi}=\max \sum_{o=1}^{o^{3}} \sum_{w=1}^{w^{0}} D I_{3 o w} X_{3 o w} ;
$$

- максимальна динамічна точність ВП:

$$
D Q^{B \Pi}=\max \sum_{o=1}^{o^{3}} \sum_{w=1}^{w^{0}} D Q_{3 o w} X_{3 o w}
$$

- максимальна статична точність ВП:

$$
S Q^{B \Pi}=\max \sum_{o=1}^{o^{3}} \sum_{w=1}^{w^{0}} S Q_{3 o w} X_{3 o w} ;
$$

- максимальний коефіцієнт перетворення ВП:

$$
K P R^{B \Pi}=\max \sum_{o=1}^{o^{3}} \sum_{w=1}^{w^{0}} K P R_{3 o w} X_{3 o w} ;
$$

- максимальна потужність вихідного сигналу ВП:

$$
W S^{B \Pi}=\max \sum_{o=1}^{o^{3}} \sum_{w=1}^{w^{0}} W S_{3 o w} X_{3 o w} ;
$$

- максимальна стійкість ВП:

$$
P U^{B \Pi}=\max \sum_{o=1}^{o^{3}} \sum_{w=1}^{w^{o}} P U_{3 o w} X_{3 o w} ;
$$

- мінімальний обсяг ВП:

$$
G^{B \Pi}=\min \sum_{o=1}^{o^{3}} \sum_{w=1}^{w^{0}} G_{3 o w} X_{3 o w} ;
$$

- мінімальна вага ВП: 


$$
P^{B \Pi}=\min \sum_{o=1}^{o^{3}} \sum_{w=1}^{w^{0}} P_{3 o w} X_{3 o w} ;
$$

- мінімальна вартість ВП:

$$
C^{B \Pi}=\min \sum_{o=1}^{o^{3}} \sum_{w=1}^{w^{0}} C_{3 o w} X_{3 o w} .
$$

Область допустимих рішень при виборі типу i виду ВП визначається обмеженнями:

- надійність ВП повинна бути більше заданої $N_{3}^{B \Pi}$ :

$$
\sum_{o=1}^{o^{3}} \sum_{w=1}^{w^{0}} N_{3 o w} X_{3 o w} \geq N_{3}^{B \Pi}
$$

- напрацювання на відмову ВП повинна бути більше заданого $\mathrm{NOT}_{3}^{B \Pi}$ :

$$
\sum_{o=1}^{o^{3}} \sum_{w=1}^{w^{0}} \mathrm{NOT}_{3 o w} X_{3 o w} \geq \mathrm{NOT}_{3}^{B \Pi}
$$

- діапазон виміру ВП повинен бути більше нижньої межі $D I_{3 H}^{B \Pi}$ і менше верхньої межі $D I_{3 B}{ }^{B \Pi}$ :

$$
D I_{3 H}^{B \Pi} \leq \sum_{o=1}^{o^{3}} \sum_{w=1}^{w^{0}} D I_{3 o w} X_{3 o w} \leq D I_{3 H}^{B \Pi}
$$

- динамічна точність ВП повинна бути більше заданої $D Q_{3}^{B \Pi}$ :

$$
\sum_{o=1}^{o^{3}} \sum_{w=1}^{w^{0}} D Q_{3 o w} X_{3 o w} \geq D Q_{3}^{B \Pi}
$$

- статична точність ВП повинна бути більше заданої $S Q_{3}^{B \Pi}$ : 


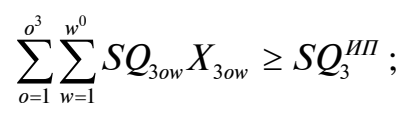

- коефіцієнт перетворення ВП повинен бути більше заданого $K P R_{3}^{B \Pi}$ :

$$
\sum_{o=1}^{o^{3}} \sum_{w=1}^{w^{0}} K P R_{3 o w} X_{3 o w} \geq K P R_{3}^{B \Pi}
$$

- потужність вихідного сигналу ВП повинна бути більше заданої $W S_{3}^{B \Pi}$ :

$$
\sum_{o=1}^{o^{3}} \sum_{w=1}^{w^{0}} W S_{3 o w} X_{3 o w} \geq W S_{3}^{B \Pi}
$$

- стійкість ВП повинна бути більше заданої $P U_{3}^{B \Pi}$ :

$$
\sum_{o=1}^{o^{3}} \sum_{w=1}^{w^{0}} P U_{3 o w} X_{3 o w} \geq P U_{3}^{B \Pi}
$$

Параметри ВП ( $G X_{3 o w}$ - ширина, $C Y_{\text {3ow }}$ - довжина, $G Z_{\text {3ow }}$ висота), повинні бути менше заданих $G X_{3}^{B \Pi}, G Y_{3}^{B \Pi}, G Z_{3}^{B \Pi}$ :

$$
\left\{\begin{array}{l}
\sum_{o=1}^{o^{3}} \sum_{w=1}^{w^{0}} G X_{3 o w} X_{3 o w} \leq G X_{3}^{B \Pi} \\
\sum_{o=1}^{o^{3}} \sum_{w=1}^{w^{0}} G Y_{3 o w} X_{3 o w} \leq G Y_{3}^{B \Pi} \\
\sum_{o=1}^{o^{3}} \sum_{w=1}^{w^{0}} C Z_{3 o_{w}} X_{3 o w} \leq G Z_{3}^{B \Pi}
\end{array}\right.
$$

- вага ВП повинна бути менше заданої $P_{3}^{\text {BП }}$ : 


$$
\sum_{o=1}^{o^{3}} \sum_{w=1}^{w^{0}} P_{3 o w} X_{3 o w} \leq P_{3}^{B \Pi}
$$

- вартість ВП повинна бути менше заданої $C_{3}{ }^{B \Pi}$ :

$$
\sum_{o=1}^{o^{3}} \sum_{w=1}^{w^{0}} C_{3 o w} X_{3 o w} \leq C_{3}^{B \Pi}
$$

- $з$ безлічі типів і видів ВП може бути обраний тільки один:

$$
\sum_{o=1}^{o^{3}} \sum_{w=1}^{w^{0}} X_{3 o w}=1 .
$$

Математична модель (70) - (92) відноситься до завдань лінійного багатокритеріального дискретного програмування 3 булевими змінними.

Блок сполучення (БС) вибирається в залежності від типів і видів обраних блоків ШП і елементів САУ. Модель вибору типу і виду БС аналогічна для розглянутих вище елементів САУ.

\section{6. Модель вибору типів і видів зв'язків між блоками ШП та елементами САУ}

Усі блоки ШП і елементи САУ інформаційно пов'язані один 3 одним і ці зв'язки відображені в матрицях інцидентності, які являють собою квадратні матриці розмірністю $v^{\prime}+m^{\prime}$ заповнені одиницями або нулями, одиниця встановлюється, якщо є зв'язок між обраними компонентами ШП, нуль - в іншому випадку.

Для параметричного синтезу зв'язків між блоками ШП i елементами САУ був введений параметр $U_{a l}=\{0,1\}$.

Для синтезу цих зв'язків відомо:

- безліч типів зв'язків $S T=\left\{S T^{S}\right\}, s=1, s^{\prime}$;

- безліч видів зв'язків в кожному типі $S T^{s}=\left\{S T_{y}^{s}\right\} ; y=1, y^{s}$.

Введемо змінну $X_{a l s y}=\{0 ; 1\}$, де $X_{\text {alsy }}=1$, якщо обрана лінія зв'язку $s$-го типу $a-M$-го виду між і 1 -м блоками і елементами ШП САУ, $X_{a l s y}=0-$ в іншому випадку. 
Необхідно визначити тип і вид зв'язків між блоками ШП і елементами САУ за обраними критеріями і обмеженням.

Кожен тип і вид зв'язків, характеризується низкою показників.

- функціональні:

1) надійність зв'язку $-N_{\text {alsy }}$;

2) напрацювання на відмову зв'язку - $N O T_{a l s y}$;

3) перешкодозахищеність зв'язку $-P Z_{a l s y}$;

4) швидкість передачі даних - $V D_{a l s y}$;

\section{- витратні:}

1) вартість зв'язку $-C_{\text {alsy }}$.

Параметричний синтез зв'язку між блоками і елементами ШП САУ можна оцінити за такими критеріями:

- максимальна надійність зв'язку:

$$
\begin{aligned}
& F^{C}\left(X_{a l s y}\right)=\max \sum_{a=1}^{v^{\prime}+m^{\prime}} \sum_{l=1}^{v^{\prime}+m^{\prime}} \sum_{s=1}^{s^{\prime}} \sum_{y=1}^{y^{s}} N_{a l s y} U_{a l} X_{a l s y} ; \\
& a \neq l ; \forall U_{a l}=1
\end{aligned}
$$

- максимальне напрацювання на відмову зв’язку:

$$
\begin{aligned}
& F^{C}\left(X_{a l s y}\right)=\max \sum_{a=1}^{v^{\prime}+m^{\prime}} \sum_{l=1}^{v^{\prime}+m^{\prime}} \sum_{s=1}^{s^{\prime}} \sum_{y=1}^{y^{s}} N O T_{a l s y} U_{a l} X_{a l s y} ; \\
& a \neq l ; \forall U_{a l}=1
\end{aligned}
$$

- максимальна перешкодозахищеність зв'язку:

$$
\begin{aligned}
& F^{C}\left(X_{a l s y}\right)=\max \sum_{a=1}^{v^{\prime}+m^{\prime}} \sum_{l=1}^{v^{\prime}+m^{\prime}} \sum_{s=1}^{s^{\prime}} \sum_{y=1}^{y^{s}} P Z_{a l s y} U_{a l} X_{a l s y} ; \\
& a \neq l ; \forall U_{a l}=1
\end{aligned}
$$

- максимальна швидкість передачі даних: 


$$
\begin{aligned}
& F^{C}\left(X_{a l s y}\right)=\max \sum_{a=1}^{v^{\prime}+m^{\prime}} \sum_{l=1}^{v^{\prime}+m^{\prime}} \sum_{s=1}^{s^{\prime}} \sum_{y=1}^{y^{s}} V D_{a l s y} U_{a l} X_{a l s y} ; \\
& a \neq l ; \forall U_{a l}=1
\end{aligned}
$$

- мінімальна вартість:

$$
\begin{aligned}
& F^{C}\left(X_{a l s y}\right)=\min \sum_{a=1}^{v^{\prime}+m^{\prime}} \sum_{l=1}^{v^{\prime}+m^{\prime}} \sum_{s=1}^{s^{\prime}} \sum_{y=1}^{y^{s}} C_{a l s y} U_{a l} X_{a l s y} ; . \\
& a \neq l ; \forall U_{a l}=1
\end{aligned}
$$

Область допустимих рішень під час вибору типу і виду зв'язку визначається обмеженнями:

- надійність кожного зв'язку повинна бути більше заданої $N_{3}^{a l}$ :

$$
\begin{aligned}
& \sum_{s=1}^{s^{\prime}} \sum_{y=1}^{y^{\prime}} N_{a l s y} U_{a l} \overline{\bar{X}}_{a l s y} \geq N_{3}^{a l} ; \\
& a, l=\overline{1, v^{\prime}+m^{\prime}} ; a \neq l ; \forall U_{a l}=1
\end{aligned}
$$

- напрацювання на відмову кожного зв'язку повинна бути більше заданого $\mathrm{NOT}_{3}^{a l}$ :

$$
\begin{aligned}
& \sum_{s=1}^{s^{\prime}} \sum_{y=1}^{y^{\prime}} \operatorname{NOT}_{a l s y} U_{a l} \overline{\bar{X}}_{a l s y} \geq \operatorname{NOT}_{3}^{a l} ; \\
& a, l=\overline{1, v^{\prime}+m^{\prime}} ; a \neq l ; \forall U_{a l}=1
\end{aligned}
$$

- перешкодозахищеність кожного зв'язку повинна бути більше заданої $P Z_{3}^{a l}$

$$
\begin{aligned}
& \sum_{s=1}^{s^{\prime}} \sum_{y=1}^{y^{\prime}} P Z_{a l s y} U_{a l} \overline{\bar{X}}_{a l s y} \geq P Z_{3}^{a l} ; \\
& a, l=\overline{1, v^{\prime}+m^{\prime}} ; a \neq l ; \forall U_{a l}=1
\end{aligned}
$$


- швидкість передачі даних кожного зв'язку повинна бути більше заданої $V D_{3}^{a l}$ :

$$
\begin{aligned}
& \sum_{s=1}^{s^{\prime}} \sum_{y=1}^{y^{\prime}} V D_{a l s y} U_{a l} \overline{\bar{X}}_{a l s y} \geq V D_{3}^{a l} ; \\
& a, l=\overline{1, v^{\prime}+m^{\prime}} ; a \neq l ; \forall U_{a l}=1
\end{aligned}
$$

- вартість кожного зв'язку повинна бути менше заданої $C_{3}^{a l}$ :

$$
\begin{aligned}
& \sum_{s=1}^{s^{\prime}} \sum_{y=1}^{y^{\prime}} C_{a l s y} U_{a l} \overline{\bar{X}}_{a l s y} \geq C_{3}^{a l} ; \\
& a, l=\overline{1, v^{\prime}+m^{\prime}} ; a \neq l ; \forall U_{a l}=1
\end{aligned}
$$
тільки один:

$$
\sum_{s=1}^{s^{\prime}} \sum_{y=1}^{y^{\prime}} \overline{\bar{X}}_{a l s y}=1 ; a, l=\overline{1, v^{\prime}+m^{\prime}} ; a \neq l .
$$

Математична модель (93) - (103) відноситься до завдань лінійного багатокритеріального дискретного програмування 3 булевими змінними.

\section{7. Модель вибору програмного засобу \\ для імітаційного моделювання ШП}

Для оцінки ефективності обраного набору блоків ШП і елементів САУ необхідно провести імітаційне моделювання їх функціонування. Це можливо зробити за допомогою спеціалізованого програмного засобу (ПЗ). На даний час відома велика кількість ПЗ, які забезпечують чисельні способи і методи моделювання одного і того ж процесу або об'єкта, що дозволяє моделювати складні системи. Для кожного способу передбачені свої набори бібліотечних елементів. Тому завдання полягає в тому, щоб вибрати такі ПЗ, які забезпечать розв'язання зазначеного завдання та нададуть, після процесу моделювання, пакет інформації в зручному вигляді для подальшого аналізу ефективності ШП. Під 
час реалізації цих функцій повинні забезпечувати мінімальні витрати часу та фінансів.

Відомо безліч ПЗ моделювання $M=\left\{M_{t}\right\}, t=\overline{1, t^{\prime}}$, де $t^{\prime}-$ число ПЗ моделювання, кожен 3 яких забезпечує можливість побудови імітаційної моделі функціонування синтезованої ШП і її САУ.

Введемо змінну $\hat{X}_{t}=\{0,1\}$, де $\hat{X}_{t}=1$, якщо вибрано $t$-ий програмний засіб моделювання, $\hat{X}_{t}=0-$ в іншому випадку.

Кожна імітаційна модель, що синтезується ПЗ моделювання, характеризується низкою показників:

\section{- функціональні:}

1) адекватність імітаційної моделі - $A_{t}^{\Pi 3}$;

2) кількість параметрів ШП, що відображаються імітаційної моделлю; $I_{t}^{\Pi 3}$;

3) кількість елементів імітаційної моделі, які можна редагувати $U R_{t}^{\Pi 13}$

4) машинний час, необхідний для роботи імітаційної моделі $T M_{t}^{\Pi 3}$;

\section{- витратні:}

1) вартість ПЗ - $C_{t}^{\Pi 3}$;

2) час синтезу імітаційної моделі - $T S M_{t}^{\Pi 13}$.

Вибір ПЗ моделювання ШП має проводитись за такими критеріями:

- максимальна адекватність імітаційної моделі:

$$
A^{\Pi 3}=\max \sum_{t=1}^{t^{\prime}} A_{t}^{\Pi 3} \hat{X}_{t}
$$

- максимальна кількість параметрів ШП, що відображаються імітаційної моделлю:

$$
I^{\Pi 3}=\max \sum_{t=1}^{t^{\prime}} I_{t}^{\Pi 3} \widehat{X}_{t}
$$

- максимальна кількість елементів імітаційної моделі, які можна редагувати: 


$$
U R^{\Pi 3}=\max \sum_{t=1}^{t^{\prime}} U R_{t}^{\Pi 3} \widehat{X}_{t}
$$

- мінімальний машинний час, необхідний для роботи імітаційної моделі:

$$
T M^{\Pi 3}=\max \sum_{t=1}^{t^{\prime}} T M_{t}^{\Pi 3} \hat{X}_{t}
$$

- мінімальна вартість ПЗ:

$$
C^{\Pi 3}=\max \sum_{t=1}^{t^{\prime}} C_{t}^{\Pi 3} \widehat{X}_{t}
$$

- мінімальний час синтезу імітаційної моделі:

$$
T S M^{\Pi 3}=\max \sum_{t=1}^{t^{\prime}} T S M_{t}^{\Pi 3} \widehat{X}_{t}
$$

Область допустимих рішень під час вибору ПЗ визначається обмеженнями:

- адекватність імітаційної моделі повинна бути більше заданої $A_{3}^{\Pi 3}$ :

$$
\sum_{t=1}^{t^{\prime}} A_{t}^{\Pi 3} \widehat{X}_{t} \geq A_{3}^{\Pi 3}
$$

- кількість параметрів ШП, що відображаються імітаційної моделлю, має бути більше заданих $I_{3}^{\Pi 3}$ :

$$
\sum_{t=1}^{t^{\prime}} I_{t}^{\Pi 3} \widehat{X}_{t} \geq I_{3}^{\Pi 3}
$$

- кількість елементів імітаційної моделі, які можна редагувати, має бути більше заданого $U R_{3}^{\Pi 3}$ : 


$$
\sum_{t=1}^{t^{\prime}} U R_{t}^{\Pi 3} \widehat{X}_{t} \geq U R_{3}^{\Pi 3}
$$

- машинний час, необхідний для роботи імітаційної моделі, має бути менше заданого $T M_{3}^{\Pi 3}$ :

$$
\sum_{t=1}^{t^{\prime}} T M_{t}^{\Pi 3} \widehat{X}_{t} \geq T M_{3}^{\Pi 3}
$$

- вартість ПЗ повинна бути менше заданої $C_{3}^{\text {ПЗ }}$ :

$$
\sum_{t=1}^{t^{\prime}} C_{t}^{\Pi 3} \widehat{X}_{t} \geq C_{3}^{\Pi 3}
$$

- час синтезу імітаційної моделі має бути менше заданого $\operatorname{TSM}_{3}^{\Pi 3}$ :

$$
\sum_{t=1}^{t^{\prime}} \operatorname{TSM}_{t}^{\Pi 3} \widehat{X}_{t} \geq \operatorname{TSM}_{3}^{\Pi 3}
$$

- $з$ безлічі ПЗ може бути вибрано тільки одне:

$$
\sum_{t=1}^{t^{\prime}} \widehat{X}_{t}=1
$$

Наведена математична модель (104) - (116) відноситься до завдань лінійного багатокритеріального дискретного програмування з булевими змінними.

\section{ВИСНОВКИ}

У роботі розроблено узагальнену модель параметричного синтезу САУ та окремі моделі параметричного синтезу елементів САУ. Ці моделі дозволяють 3 єдиних критеріальних позицій комплексно вирішити задачу системного синтезу САУ за багатьма критеріями. 
Розроблено модель оцінки і вибору типів і видів зв'язків між блоками ШП і елементами САУ. Ця модель, на відміну від наявних, дозволяє оцінити за багатьма критеріями всі типи і види зв'язків, що містяться в ШП і вибрати ефективну.

Дані моделі використовуються під час проектування та модернізації систем управління штампового оснащення та прогнозування його довговічності 3 метою забезпечення експлуатаційної надійності й довговічності машин, агрегатів і деталей.

\section{АНОТАЦІЯ}

У даній роботі розглянуті критерії ефективності моделей параметричного синтезу системи автоматичного управління, а також розроблені математичні моделі підвищення ефективності і оперативності прийнятих рішень під час синтезу систем автоматизованого управління за рахунок обгрунтованого вибору іiі елементів. Дані моделі використовуються під час проектування штампового оснащення та прогнозування його довговічності 3 метою забезпечення експлуатаційної надійності й довговічності машин, агрегатів i деталей. Розроблено узагальнену модель параметричного синтезу САУ та окремі моделі параметричного синтезу складових елементів САУ (мікроконтролер, частотний перетворювач, вимірювальний перетворювач). Усі ці моделі, на відміну від наявних, дозволяють з єдиних критеріальних позицій комплексно вирішити задачу системного синтезу САУ за багатьма критеріями. Розроблено модель оцінки і вибору програмного забезпечення для імітаційного моделювання функціонування як усього технологічного процесу виробництва електронних компонентів РЕА, так і окремо кожного іï блоку, що дасть можливість підвищити ефективність процесу моделювання шляхом створення всіх елементів ТП, взаємозв'язків між ними і алгоритму роботи САУ.

Сучасне приладобудування розвивається в напрямку автоматизації виробництва 3 широким використанням САУ, впровадження гнучких технологій дозволяє швидко і ефективно перебудовувати технологічні процеси на виготовлення нових виробів.

Застосування САУ дозволяє значно підвищити продуктивність обладнання, гнучкість виробництва, скоротити чисельність робітників, а значить, знизити частку ручної праці і суттєво 296 
підвищити якість і надійність продукції, що випускається. У зв'язку iз цим розроблення систем управління для впровадження в наявне неавтоматизоване обладнання i ïx застосування під час проектування нових автоматизованих комплексів дозволить підвищити якість продукції, що випускається і знизити економічні витрати, що $є$ актуальним завданням.

\section{ЛІТЕРАТУРА}

1. Lutsenko I. Deployed model of extremal system operation for solving optimal management problems. Eastern-European Journal of Enterprise Technologies. 2014. 5/2(71). P. 61-66. DOI: 10.15587/17294061.2014.28592.

2. Lutsenko I. Optimal control of systems engineering. Development of a general structure of the technological conversion subsystem. Eastern-European Journal of Enterprise Technologies. 2015. Vol. 1, Issue 2 (73). P. 43-50. DOI: 10.15587/1729-4061.2015.36246.

3. Клещов Г.М. Інформаційні конструкторські масиви штампів холодної листової штамповки. Вісник Інженерної академії України. 2010. №3. С. 74-77.

4. Калюжний В.Л. Холодне штампування виробу з двома фланцями із листової заготовки шляхом використання операцій витягування, роздачі i осаджування. Збірник наукових пращь Полтавського національного технічного університету ім. Ю. Кондратюка. Сер.: Галузеве машинобудування, будівнищтво. 2013. № 2. C. 105-110.

5. Шамарін Ю.С., Тітов В.А., Носар С.А. Напрямки модернізації штамувального обладнання. Journal of Mechanical Engineering NTUU «Kyiv Polytechnic Institute». 2011. № 62. C. 92-94.

6. Калюжний В.Л. Створення інформаційних технологій реалізації інтенсивного пластичного деформування матеріалів та поверхневого зміцнення при виготовленні деталей для забезпечення надійності та довговічності штампів: звіт про НДР (заключ.). НТУУ «КПI». 2010.

7. Мосьпан Д.В. Наумова Е.А., Воронин А.В., Драгобецкий В.В. Корректировка режимов упрочнения пластическим деформированием. Вестник Наи. техн. ун-та «ХПИ» : сб. науч. тр. Темат. вып. : Инновационные технологии и оборудование обработки материалов в машиностроении и металлургии. Харьков : НТУ «ХПИ». 2014. № 43(1086). С. 117-122.

8. Невлюдов І.Ш., Токарєва О.В. Автоматичне управління технологічними об’єктами : підручник. Київ : НАУ, 2018. 200 с. 
9. Lutsenko I., Fomovskaya E. Identification of target system operations. The practice of determining the optimal control. EasternEuropean Journal of Enterprise Technologies. 2014. № 6(2(78)). P. 30-36. DOI: 10.15587/1729-4061.2015.54432.

10. Zhang, S., Zhang C., Han G., Wang Q. Optimal Control Strategy Design Based on Dynamic Programming for a Dual-Motor CouplingPropulsion System. The Scientific World Journal. 2014. Vol. 2014. P. 1-9. DOI: 10.1155/2014/958239/.

11. Lapygin Y., Prokhorov N. Cost Management in the enterprise. Eksmo, 2007. 102 p.

12. Lutsenko I. Identification of target system operations. Development of global efficiency criterion of target operations. EasternEuropean Journal of Enterprise Technologies. 2015. Vol. 2, Issue 2(74). P. 35-40. DOI: 10.15587/1729-4061.2015.38963.

13. Дорф Р., Бишоп Р. Современные системы управлени /. Пер. с англ. Б.И. Копылова. Москва : Лаборатория Базовых Знаний, 2002. $832 \mathrm{c}$.

14. Парк Д., Маккей С. Сбор данных в системах контроля и управления. Москва : Группа ИДТ, 2006. 504 с.

15. Гульков Г.И., Петренко Ю.Н., Раткевич Е.П., Симоненков О.Л. Системы автоматизированного управления електро-приводами. Москва : Новое знание, 2007. 400 с.

16. Парр Э. Программируемые контроллеры. Руководство для инженера. Programmable Controllers: An Engineer's Guide. Москва : Бином. Лаборатория знаний, 2007. 520 с.

17. Трамперт В. Измерение, управление и регулирование с помощью AVR микрокон-троллеров. Messen, Steuem und Regeln mit AVR-Mikrocontrollem. Москва : МК-Пресс, 2006. 208 с.

\section{Information about authors:} Mospan D. V.,

Candidate of Engineering Science, Associate Professor, Associate Professor of Department of Electronic Devices Kremenchuk Mykhailo Ostrohradskyi National University 20, Pershotravneva str., Kremenchuk, Poltava region, 39600, Ukraine

Fomovskaya O. V., Candidate of Engineering Science, Associate Professor,

Head of Department of Electronic Devices Kremenchuk Mykhailo Ostrohradskyi National University 20, Pershotravneva str., Kremenchuk, Poltava region, 39600, Ukraine 